\title{
Utilization of the Time Driven Activity Based Costing Method in Determining the Cost of Room Rent at Hotel Tampiarto Probolinggo
}

\author{
Tatik Amani ${ }^{*}$, Khusnik Hudzafidah ${ }^{2}$, HanifahIndah Wulandari ${ }^{3}$
}

1,2,3 Faculty of Economics, Panca Marga University, Probolinggo, Indonesia

\section{ART ICLE IN F O}

\section{Article history:}

Received September 02, 202

Revised September 03, 2021

Accepted October 23, 2021

Available online November 25, 2021

Keywords:

Cost Of Renting A Room Traditional Costing, TDABC

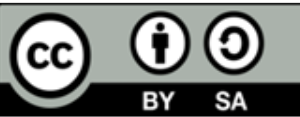

This is an open access article under the CC BY-SA license.

Copyright (C) 2021 by Author. Published by Universitas Pendidikan Ganesha.

\begin{abstract}
A B S T R A C T
The determination of the cost of renting a room at the Hotel Tampiarto Probolinggo is currently still using traditional methods that lack accuracy. Time driven activity-based costing method can solve these problems by presenting an accurate cost of room rental. This study aims to calculate and present hotel room rental prices with the time driven activity-based costing method and to find out the difference between the traditional method and the time driven activity-based costing method. The method in this research is descriptive qualitative with a case study approach. The subject of this study is the rental price of all rooms at Hotel Tampiarto Probolinggo. The results of calculations and analysis in this study indicate that the calculation of the cost of renting a hotel room with the Time Driven Activity Based Costing method can be applied by Hotel Tampiarto because the results show that the allocation of costs for each activity based on the time required produces a more accurate and efficient cost of renting a room with the average efficiency rate of each room is $8 \%$ to $30 \%$ of the current price of traditional methods.With the cost of goods using the time driven activity based costing method, management can make business strategies to increase room rental income by making new strategies, especially for the type of room with the lowest sales level with cheaper room rental costs.
\end{abstract}

\section{INTRODUCTION}

The increasingly fierce competition in the hospitality services business has forced hoteliers to carry out innovative strategies to attract customers. The quality of services provided to consumers is the main thing that service companies must pay attention to. In addition to quality, service and price are very influential factors in winning the hearts of consumers and potential consumers (Suratinoyo, 2013). In a business that certainly provides products or services, the strategy of setting prices is an important thing that must be taken into account by the management (Devine, 2016). Price Determination of the cost of renting a room at Hotel Tampiarto Probolinggo is currently still using the traditional method whose calculation accuracy is lacking because there are distorted costs. With this traditional approach, under costing and over costing events are more likely to occur (Kamaliah, 2018). The time driven activity-based costing method can solve these problems by presenting an accurate cost of room rental. This is in line with previous researchers, the TDABC method is a new breakthrough in the world of temporary accounting for calculating product costs (Kurniawansyah, 2020). Accurate calculation of cost of services is a very important part for companies to gain an advantage in the competition (Juanelo Ryan, 2018).

Cost of goods serves as the basis for determining the selling price, determining the amount of profit, monitoring the efficiency of the company, assisting management in making decisions, and the basis for preparing financial statements (Jovanka \& Faliany, 2017). The calculation of the cost of goods is inseparable from costs which are an important factor and must be calculated correctly and precisely in achieving the objectives of business activities to gain profits. To increase the profitability of a company, the company must be able to determine the selling price of the right product (Tandiontong, 2011). Most service companies currently still use the traditional financing allocation system in calculating the cost of their products (Indira Kristina, 2016). This is because the calculation of the cost of services using the traditional method is simple and easy to calculate. However, product cost distortions can occur in traditional cost accounting systems (Kaunang et al., 2015). In the traditional system, overhead costs will be assigned to service products based on unit level activity drivers, namely in one unit or direct labor hours. The allocation with traditional 
financing can cause the determination of the cost of goods and services to be less accurate. Therefore, a new method emerged in calculating the cost of production known as activity based costing (Danang Rahmaji, 2013). This agrees with the research of Winarno and his friends. Determination of unit costs can use various methods, one of which is using Activity Base Costing (ABC) (Winarno, Eko Nugroho, 2014).

The Activity Based Cost $(\mathrm{ABC})$ system identifies various kinds of activities carried out by the company during the production process. The product costing approach in this system assigns costs to products or services based on the consumption of resources by activities. However, in its implementation, although the Activity based costing system has benefits, it also has several obstacles, including the data used is subjective and difficult to validate, the interview and survey process requires a lot of time and money, and is expensive to store, process, and report data. Activity Based Costing can be concluded as an approach to determining the cost of products or services based on resource consumption caused by activities (Th.A.Sumilat, 2013). The weakness of $\mathrm{ABC}$ led to the idea of improving ABC called Time Driven Activity Based Costing (TDABC) (Oktavia et al., 2017). A simple, easy-to-apply and inexpensive cost-of-cost method is needed (Hariyati, 2018). This new system is designed to reduce the complexity of calculating activitybased costs (Mira Ely, Rochman Effendi, 2019).

The determination of the right selling price must be supported by an accurate calculation of the cost of production, because the main component of the selling price is the cost of production (Bayangkara, 2019). The cost of production has a very important role in determining the selling price of the product (Satria, 2017). The method of determining production costs is a way of calculating the elements of cost into production costs (Baihaqi et al., 2018). The determination of the cost of production is used for calculating the company's profit or loss which will be reported to the company's external parties (Kaukab, 2019).

Conventional methods (single and departmental rates) tend to be less accurate in assigning overhead costs to these products because the conventional approach simplifies the production process of a product or service. Different products are assumed to only use an asset in the entire production process or in one particular department. Traditional calculation methods often give inaccurate results if you look at the condition of companies that have a lot of activities (Rotikan, 2013). As an innovation from traditional costing, Activity-Based Costing ( $\mathrm{ABC}$ ) emerged with the aim of getting the right allocation of overhead costs to activities or related resource use so as to produce the right allocation of costs to, orders, products and customers (Feny Triagustina \& Gani, 2021). This activity-based costing calculation is based on the concept of products that consume activities and activities that consume resources which ultimately incur costs (Dewi \& Agustia, 2014). Activity Based costing (ABC) is about system that identified the activities progress and calculate the detail of price of the activities for all the product anc services (Ramintang \& Pangemanan, 2016).

Time-driven activity-based costing is an approach in cost accounting that is cheaper and easier than activity-based costing systems. With time-driven activity-based costing, resource usage is only caused by the time it takes to perform the activity (Hartono, 2021). In TDABC, the activity costs of products and services are determined by the principle that those that consume costs or resources are activities that can be measured and estimated in the amount of time (Azmi, 2018). Direct and indirect costs are calculated using TDABC, then the results from TDABC are compared with calculations made by the hotel. The results of this study indicate that the TDABC method can be applied to hotel service costs, the cost capacity level can be calculated more accurately and flexibly (Riediansyaf, Mertzha Dwiputri; Basuki, 2014). The implementation of TDABC also assists managers in taking follow-up actions to reduce time on redundant activities to increase hotel profitability. This study aims to calculate and present hotel room rental prices with the time driven activity-based costing method and to find out the difference between the traditional method and the time driven activity-based costing method.

\section{METHODS}

The research method used is qualitative descriptive method with a case study approach, namely an empirical inquiry that investigates phenomena in the context of real life. This study will explain the main research variable, namely the cost of renting a room using the Time Driven Activity Based Costing method. Descriptive research aims to create a description, a systematic, factual and accurate description of a fact, nature and relationship between the phenomena studied. Descriptive research is a problem formulation with regard to the question of the existence of independent variables, either only on one or more variables (stand-alone variables) (Sugiyono, 2014). This study aims to analyze the flood disaster mitigation policy in Lamongan Regency, then provide policy alternatives as recommendations to the Lamongan Regency Government, especially the Lamongan Regency Regional Disaster Management Agency (BPBD) in its steps to overcome floods that always occur in Lamongan Regency. In this study, policy alternatives were compiled as a result of 5 (five) stages of policy analysis namely: formulating problems in policies, determining goals and objectives, identifying policy parameters, seeking policy alternatives, 
and deciding alternative options. In the implementation of these 5 (five) stages, data analysis is carried out carefully on the data that has been obtained through official documents and literature reviews from the Google Scholar and Research Gate sites (Badjuri \& Abdulkahar, 2003).

\section{RESULTS AND DISCUSSIONS}

\section{Results}

Room Service Fee Allocation for One Year

The cost data used in this study is data from 2018 before the Covid-19 pandemic. The costs considered in determining the allocation of room service costs are direct labor costs, direct materials and overhead costs. Table 1 shows the Allocation of Labor Costs for One Year on Room Service Services.

Table 1. Allocation of Labor Costs for One Year on Room Service Services

\begin{tabular}{|c|c|c|c|c|c|}
\hline NO & POSITION & $\begin{array}{l}\text { SALARY PER } \\
\text { MONTH }\end{array}$ & $\begin{array}{l}\text { ALLOWANCE } \\
\text { (IDR) }\end{array}$ & LABOR & $\begin{array}{l}\text { LABOR COST PER YEAR } \\
\text { (IDR) }\end{array}$ \\
\hline 1 & Reservasi & 2.300 .000 & 500.000 & 2 & 67.200 .000 \\
\hline 2 & GSA & 2.300 .000 & 500.000 & 2 & 67.200 .000 \\
\hline 3 & Bell drive & 2.300 .000 & & 2 & 55.200 .000 \\
\hline 4 & GRO VIP & 2.300 .000 & 800.000 & 1 & 37.200 .000 \\
\hline 5 & Room Attendent & 2.300 .000 & & 6 & 165.600 .000 \\
\hline 6 & $\begin{array}{l}\text { Staff procce -sing } \\
\text { laundry }\end{array}$ & 2.300 .000 & & 5 & 138.000 .000 \\
\hline 7 & $\begin{array}{c}\text { Staff counter } \\
\text { laundry }\end{array}$ & 2.300 .000 & & 2 & 55.200 .000 \\
\hline 8. & Runner & 2.300 .000 & & 2 & 55.200 .000 \\
\hline 9. & $\begin{array}{l}\text { Receptionist kolam } \\
\text { renang }\end{array}$ & 2.300 .000 & & 3 & 82.800 .000 \\
\hline \multicolumn{5}{|c|}{ Total Labor Cost for 1 Year } & 723.600 .000 \\
\hline
\end{tabular}

In addition to direct labor costs, the value of the cost of room service is also influenced by the amount of direct material costs such as bathing needs, as well as instant drink facilities in the room. Table 2 shows the direct material cost.

Table 2. Direct Material Cost

\begin{tabular}{cccc}
\hline NO & NAME OF GOOD & UNIT COST (IDR) & NEED PER YEAR (IDR) \\
\hline 1 & Mineral Water 600 ml & 2.000 & 6.278 .000 \\
2 & Cofee & 900 & 2.825 .100 \\
3 & Sugar & 900 & 2.825 .100 \\
4 & Tea & 900 & 2.825 .100 \\
5 & Shampoo & 1.000 & 3.139 .000 \\
6 & Soap & 1.000 & 3.139 .000 \\
7 & Toothache and Toothpaste & 2.000 & 6.278 .000 \\
8 & Shower Cup & 500 & 1.569 .000 \\
9 & Towel & 5.000 & 15.695 .000 \\
10 & Flip & 2.000 & 6.278 .000 \\
\hline
\end{tabular}

Total Direct Material Cost for 1 Year

50.851 .300

Another cost element that affects the cost of room service is overhead costs. The overhead costs considered in determining the cost of room service at the Tampiarto hotel are the costs of electricity, water, telephone, wifi, and room cleanliness as shown in Table 3.

Table 3. Allocation of overhead costs for a year on room service

\begin{tabular}{ccc}
\hline NO & OVERHEAD TYPE & COST ALLOCATION PER YEAR \\
\hline 1. & Electricity & 83.000 .000 \\
2. & Water & 78.000 .000 \\
3. & Phone, wifi & 27.000 .000 \\
4. & Depreciation & 43.455 .000 \\
5 & Room Cleanliness, ect & 42.000 .000 \\
\hline Total Overhead Cost Allocation for 1 year & $\mathbf{2 7 3 . 4 5 5 . 0 0 0}$ \\
\hline
\end{tabular}




\section{Activity Identification}

Reservation activity is a hotel room reservation service. Room reservation services can be made by telephone or online reservations served by the reservation section while reservations on the frontdesk are served by GSA (guest service agent). Table 4 shows the front desk service activities in the Tampiarto hotel.

Table 4. Front desk Service Activities

\begin{tabular}{lll}
\hline NO & \multicolumn{1}{c}{ Activity } & \multicolumn{1}{c}{ Sub Activity } \\
\hline 1. & Online Reservations & - Check the list of room orders on the online system \\
& & - Entering data in the online system to order data on the computer \\
2. & Reservations by & - Greeting \\
& Phone & - Asking customer wishes \\
& & - Offers available room types and prices \\
& & - Record room reservation on computer \\
\hline
\end{tabular}

In this study, there were three main activities observed, namely check-in, checkout and reservation activities. Those activities is described in Table 5.

Table 5. Check in, Checkout, and Reservation Activities

\begin{tabular}{|c|c|c|}
\hline NO & Activity Type & Activity Description \\
\hline 1. & Check In & Recording customer identity and giving room keys \\
\hline 2. & Check Out & $\begin{array}{l}\text { Check out service activities in the form of billing activities, receipt of } \\
\text { payments and receipt of room keys. }\end{array}$ \\
\hline 3. & Reservation & $\begin{array}{l}\text { Reservations can also be made directly at the front office. GSA will record } \\
\text { the identity of the order and also the date ordered }\end{array}$ \\
\hline
\end{tabular}

Each activity on the front desk service consists of several sub-activities

The activity of dropping off guests only occurs when the guest needs help carrying luggage to the room. In addition, the activity of delivering guests also takes precedence if the guest is classified as a VIP guest. Table 6 shows the drop off activities and sub activities, and Table 7 shows the activity setting up menu.

Table 6. Drop Off Activities

\begin{tabular}{ll}
\hline \multicolumn{1}{c}{ Activities } & \multicolumn{1}{c}{ Sub Activities } \\
\hline Drop Off Activities & Greeting \\
& Moving customer goods to the cart \\
& Deliver customers / guests to the room \\
\hline
\end{tabular}

Table 7. Activity Setting up menu

\begin{tabular}{|c|c|c|}
\hline No & Sub Activity & Description/Activites \\
\hline 1 & Preparing the menu & $\begin{array}{l}\text { This activity is a menu cooking activity in the Tampiarto Hotel } \\
\text { kitchen }\end{array}$ \\
\hline \multirow[t]{2}{*}{2} & & This activity is carried out by the executive chef of Resto \\
\hline & Controlling meal preparation & $\begin{array}{l}\text { Lekker. In the form of controlling food and beverages that will } \\
\text { be served for hotel guest dining services. }\end{array}$ \\
\hline 3 & Arrange menus and cutlery & $\begin{array}{l}\text { This activity is in the form of arranging the dining menu at the } \\
\text { restaurant }\end{array}$ \\
\hline 4 & Waiter/waitress Service & $\begin{array}{l}\text { There are two main types of waiter/waitress activities. The } \\
\text { first type is in the form of picking up leftover plates and glasses } \\
\text { on the table, cleaning the table and arranging new cutlery. The } \\
\text { second type is refill activity in the form of refilling food, drinks, } \\
\text { tissue replacing sugar and salt. }\end{array}$ \\
\hline
\end{tabular}

\section{Stages of Calculation of Room Fees with the TDABC Method}

The first stage in the TDABC model planning process at the Tampiarto hotel is how to determine the various activities that occur. This research is focused on the room division, the activity in question is activities related to room rental services. Table 8 shows the activity detail list and time unit table. 
Table 8. Activity Detail List \& Time Unit Table

\begin{tabular}{|c|c|c|c|c|}
\hline NO & $\begin{array}{l}\text { Aktivity } \\
\text { Groups }\end{array}$ & Activity Details & $\begin{array}{l}\text { Time per } \\
\text { activity } \\
\text { (minutes) }\end{array}$ & $\begin{array}{l}\text { Total time in } \\
\text { each group } \\
\text { (minutes) }\end{array}$ \\
\hline \multirow[t]{4}{*}{1.} & $\begin{array}{l}\text { Administration } \\
\text { (check in) }\end{array}$ & $\begin{array}{l}\text { Welcoming guestand ask whether you have } \\
\text { previously made a reservation or not }\end{array}$ & 1 & 6 \\
\hline & & The walk in guest records guest data. & 2 & \\
\hline & & $\begin{array}{l}\text { The reservation asks for proof of reservation } \\
\text { and does some checking }\end{array}$ & 2 & \\
\hline & & $\begin{array}{l}\text { Provide the guest room key and ask if there is } \\
\text { anything else I can help you with }\end{array}$ & 1 & \\
\hline \multirow[t]{2}{*}{2.} & $\begin{array}{l}\text { Accompanyin } \\
\text { the guest }\end{array}$ & $\begin{array}{l}\text { Carrying guest luggage and escorting guests to } \\
\text { the reserved room }\end{array}$ & 3 & 4 \\
\hline & & $\begin{array}{l}\text { A brief explanation of the facilities in the room } \\
\text { and asking if there is anything else that can be } \\
\text { helped }\end{array}$ & 1 & \\
\hline \multirow[t]{6}{*}{3} & $\begin{array}{l}\text { Adminitrasi } \\
\text { (checkin) }\end{array}$ & $\begin{array}{l}\text { The Front Office section contacts the HK } \\
\text { section to check the room whether there are } \\
\text { hotel items under by the guest and check for } \\
\text { guest items left behind }\end{array}$ & 3 & 8 \\
\hline & & $\begin{array}{l}\text { Front Office department contacted F\&B to } \\
\text { check guest bill list }\end{array}$ & 1 & \\
\hline & & $\begin{array}{l}\text { The Front Office section contacts the laundry } \\
\text { department to record the amount of guest } \\
\text { laundry }\end{array}$ & 1 & \\
\hline & & Print bills & 1 & \\
\hline & & Request guest signature and receive payment & 2 & \\
\hline & & Total & & 18 minute \\
\hline
\end{tabular}

\section{Capacity Cost Rate}

After determining the practical capacity of the resources used, the next step is to calculate the capacity rate of indirect labor for each type of room. The formula for calculating the capacity rate is to divide the total cost of labor by the practical capacity of the resources used. Calculation of capacity cost rate will produce cost partion for each minute. In addition, the capacity rate can also be used to determine the unit cost which is the most important part of the time driven activity-based costing method. Tampiarto hotel has 8 types of rooms. There is no segregation of duties regarding which employees will be tasked with serving room orders such as for example special deluxe, superior A and superior B. So to find out the actual "cost portion", the researcher uses the assumption that the more types of rooms sold, the more time employees spend for these types of rooms. Based on this assumption, the percentage used by the researcher comes from the data table of rooms that were successfully sold during 2018, as shown in Table 9.

Table 11. Data of Rooms Sold during 2018

\begin{tabular}{clcc}
\hline No & \multicolumn{1}{c}{ Room Type } & Total of room sold & Percentage \\
\hline 1. & Special Deluxe & 147 & $3,89 \%$ \\
2. & Superior A & 1.022 & $27,07 \%$ \\
3. & Superior B & 1121 & $29,70 \%$ \\
4. & Moderat & 247 & $6,54 \%$ \\
5. & Moderat Triple & 217 & $5,75 \%$ \\
6. & Family & 122 & $3,23 \%$ \\
7. & Standart Triple & 421 & $11,15 \%$ \\
8. & Standart & 478 & $12,66 \%$ \\
\hline TOTAL & $\mathbf{3 . 7 7 5}$ & $\mathbf{1 0 0 \%}$ \\
\hline
\end{tabular}

To calculate the cost of the room, the researcher uses "used capacity" as an overhead cost. For direct materials and direct labor, it is based on predetermined data, which is multiplied by the percentage of rooms sold. Table 10 shows the result of calculating room costs at the Tampiarto Hotel in 2018 using the TDABC method. 
Table 10. Comparison of Conventional Methods and TDABC Methods

\begin{tabular}{lcrrr}
\hline ROOM TYPE & $\begin{array}{l}\text { CONVENTIONAL } \\
\text { METHOD ROOM } \\
\text { PRICE (IDR) }\end{array}$ & $\begin{array}{c}\text { TDABC METHOD } \\
\text { ROOM } \\
\text { PRICE (IDR) }\end{array}$ & $\begin{array}{c}\text { DIFFERENCE } \\
\text { (IDR) }\end{array}$ & EFFICIENCY \\
\hline Special Deluxe & 495.000 & 420.399 & 74.601 & $15,07 \%$ \\
Superior A & 369.370 & 262.838 & 106.532 & $28,84 \%$ \\
Superior B & 369.370 & 260.628 & 108.742 & $29,44 \%$ \\
Moderat & 295.000 & 259.878 & 35.122 & $11,91 \%$ \\
Moderat Triple & 350.000 & 321.114 & 28.886 & $8,25 \%$ \\
Family & 600.000 & 436.214 & 163.786 & $27,30 \%$ \\
Triple Standart & 265.000 & 217.987 & 47.013 & $17,74 \%$ \\
Standart & 195.000 & 179.039 & 15.961 & $8,19 \%$ \\
\hline
\end{tabular}

\section{Discussions}

The Activity Based Cost (ABC) system identifies various kinds of activities carried out by the company during the production process. The product costing approach in this system assigns costs to products or services based on the consumption of resources by activities. However, in its implementation, although the Activity based costing system has benefits, it also has several obstacles, including the data used is subjective and difficult to validate, the interview and survey process requires a lot of time and money, and is expensive to store, process, and report data. Activity Based Costing can be concluded as an approach to determining the cost of products or services based on resource consumption caused by activities (Th.A.Sumilat, 2013). The weakness of ABC led to the idea of improving ABC called Time Driven Activity Based Costing (TDABC) (Oktavia et al., 2017). A simple, easy-to-apply and inexpensive cost-of-cost method is needed (Hariyati, 2018). This new system is designed to reduce the complexity of calculating activitybased costs (Mira Ely, Rochman Effendi, 2019).

The determination of the right selling price must be supported by an accurate calculation of the cost of production, because the main component of the selling price is the cost of production (Bayangkara, 2019). The cost of production has a very important role in determining the selling price of the product (Satria, 2017). The method of determining production costs is a way of calculating the elements of cost into production costs (Baihaqi et al., 2018). The determination of the cost of production is used for calculating the company's profit or loss which will be reported to the company's external parties (Kaukab, 2019).

Conventional methods (single and departmental rates) tend to be less accurate in assigning overhead costs to these products because the conventional approach simplifies the production process of a product or service. Different products are assumed to only use an asset in the entire production process or in one particular department. Traditional calculation methods often give inaccurate results if you look at the condition of companies that have a lot of activities (Rotikan, 2013). As an innovation from traditional costing, Activity-Based Costing (ABC) emerged with the aim of getting the right allocation of overhead costs to activities or related resource use so as to produce the right allocation of costs to, orders, products and customers (Feny Triagustina \& Gani, 2021). This activity-based costing calculation is based on the concept of products that consume activities and activities that consume resources which ultimately incur costs (Dewi \& Agustia, 2014). Activity Based costing (ABC) is about system that identified the activities progress and calculate the detail of price of the activities for all the product anc services (Ramintang \& Pangemanan, 2016).

Time-driven activity-based costing is an approach in cost accounting that is cheaper and easier than activity-based costing systems. With time-driven activity-based costing, resource usage is only caused by the time it takes to perform the activity (Hartono, 2021). In TDABC, the activity costs of products and services are determined by the principle that those that consume costs or resources are activities that can be measured and estimated in the amount of time (Azmi, 2018). Direct and indirect costs are calculated using TDABC, then the results from TDABC are compared with calculations made by the hotel. The results of this study indicate that the TDABC method can be applied to hotel service costs, the cost capacity level can be calculated more accurately and flexibly (Riediansyaf, Mertzha Dwiputri; Basuki, 2014). The implementation of TDABC also assists managers in taking follow-up actions to reduce time on redundant activities to increase hotel profitability

\section{CONCLUSION}

The calculation of room costs using the time driven activity-based costing (TDABC) method can be applied by Hotel Tampiarto, namely by using calculated activities, namely, list of activities and time units, 
practical capacity of available resources. used capacity cost rate, cost driver rate, cost of performing activities. This is because the calculation of cost of goods using time driven activity-based coting can allocate costs for each activity based on the time required to work on each service product. The resulting cost of rent is more accurate and efficient. The difference that occurs between the cost of renting a room using the traditional method and time driven activity-based costing is because the overhead costs in the traditional method are only charged to one cost driver, causing distorted costs. Meanwhile, the imposition of overhead costs on the time driven activity-based costing method based on many room rates based on 2018 data resulted in the calculation of the cost of renting rooms with an average efficiency level of $8 \%$ to $30 \%$ of the current traditional method price. Based on these more efficient results with the cost of goods using the time driven activity-based costing method, management can make business strategies to increase room rental income by making new strategies, especially for the type of room with the lowest sales level with cheaper room rental costs.

\section{REFERENCES}

Azmi, Z. (2018). Time Driven Activity Based Costing dan Implementasinya Pada Jasa Perawatan Kesehatan. Jurnal Akuntansi \& Ekonomika, V0l. 8 NO 1. https://doi.org/10.37859/jae.v11i1.1534.

Baihaqi, L. A., Mas, I., \& Sayekti, Y. (2018). Analisis Penentuan Beban Pokok Produksi Pada Usaha Tempe Sumber Mas Jember Analysis Determination Cost of Production on Businesses Tempe Sumber Mas Jember. E-Journal Ekonomi Bisnis Dan Akuntansi, V(70), 134-140. https://doi.org/10.19184/ejeba.v5i2.8648.

Bayangkara, I. (2019). Implementasi Time Driven Activity ABC (TDABC) dalam Perhitungan Harga Pokok Produksi AMDK Merk "RIO." Jurnal Ekonomi Akuntansi, 4(1), 99-117. https://doi.org/10.30996/jea17.v4i01.3291.

Danang Rahmaji. (2013). Penerapan Activity-Based Costing System Untuk Menentukan Harga Pokok Produksi PT.Celebes Mina Pratama. EMBA, 1(3), 63-73. https://doi.org/10.35794/emba.1.3.2013.1940.

Devine, M. (2016). Penerapan Metode Time Driven Activity-Based Costing Untuk Menghitung Harga Pokok Produk Jasa : Studi Kasus Salon Kecantikan AVV Make Up \& Hard D0. Jurnal Akuntansi, 9(2), 130146. https://doi.org/10.25170/jara.v9i2.23.

Dewi, T. U., \& Agustia, D. (2014). Desain Model Time Driven Activity Based Costing Dalam Menentukan Unit Cost Tarif Kamar Instalasi Merpati RSUD dr. Soedono Madiun. Ekonomi Dan Bisnis, 3, 228234. http://dx.doi.org/10.20473/jeba.V24I32014.228-234.

Feny Triagustina, \& Gani, L. (2021). Usulan Time-Driven Activity Based Costing System, Customer Profitability Analysis dan Sistem Pengendalian Internal pada Perusahaan Logistik. Jurnal Riset Akuntansi \& Perpajakan (JRAP), 8(01), 1-13. https://doi.org/10.35838/jrap.2021.008.01.01.

Hariyati. (2018). Time Driven Activity-Based Costing : Konsep Akuntansi Manajemen yang Akurat dalam Menghadapi Lingkungan yang Dinamis dan Bisnis Global. Jurnal Bisnis Dan Manajemen, 3(2), 218230. https://doi.org/10.26740/bisma.v3n2.p218-230.

Hartono, E. M. (2021). Analisis Cost-to-Serve dan customer Profitabilitas dengan Time-Driven ActivityBased Costing. Jurnal Akuntansi, 8(1), 21-33. http://dx.doi.org/10.31000/competitive.v5i1.2589.

Indira Kristina, L. J. F. (2016). Penerapan Time-Driven Activity Based Costing Pada Perhitungan Harga Pokok Produk Jasa di PR Ernest Advisory. Jurnal Akuntansi, 1, 41-51. https://doi.org/10.25170/jara.v10i1.39.

Jovanka, A. A., \& Faliany, L. J. (2017). Penerapan Time-Driven Activity-Based Costing Pada Perhitungan Harga Pokok Produk Usaha Jasa Unixon. Jurnal Akuntansi, 11(1), 12-31. https://doi.org/10.25170/jara.v11i1.49.

Juanelo Ryan, L. J. F. (2018). Penerapan Time-Driven Activity Based Costing Pada Perhitungan Harga Pokok Kamar Penginapan Pondok Impian. BALANCE, 15(1), 74-89. https://doi.org/10.25170/balance.v18i1.

Kamaliah, Z. R. N. S. (2018). Analisis Biaya Dengan Menggunakan Syistem Time Driven Aktivity Based Costing (TDABC) Sebagai Dasar Penentuan Biaya Per Mahasiswa (Unit Cost): Studi Kasus Universitas Pasir Pengarain. Paper Knowledge. Toward a Media History of Documents, 26(September), 12-26. http://dx.doi.org/10.31258/je.26.3.p.65-83.

Kaukab, M. E. (2019). Implementasi Activity-Based Costing Pada UMKM. Journal of Economic, Management, Accounting and Technology, 2(1), 69-78.. https://doi.org/10.32500/jematech.v2i1.576.

Kaunang, B., Walandouw, S. K., Akuntansi, J., Sam, U., \& Manado, R. (2015). Penerapan Metode Activity Based Costing System Dalam Menentukan Besarnya Tarif Jasa Rawat Inap Pada Rumah Sakit Umum Bethesda. 3(1), 1214-1221. https://doi.org/10.35794/emba.3.1.2015.8125. 
Kurniawansyah, D. (2020). Kinerja Umkm Di Kabupaten Jember: Studi Empiris Sebelum Dan Sesudh Penerapan Metode Time-Driven Activity-Based Costing. Jurnal Riset Akuntansi Dan Bisnis Airlangga, 5(1), 834. https://doi.org/10.31093/jraba.v5i1.207.

Mira Ely, Rochman Effendi, I. M. (2019). Penerapan Metode Time Driven Activity Based Costing (TDABC) dalam Perhitungan Kos Service pada Bengkel HBBA. Jurnal Akuntansi Universitas Jember, 17(2), 8291. https://doi.org/10.19184/jauj.v17i2.10709.

Oktavia, D., Studi, P., Fakultas, A., \& Jember, U. (2017). Implementasi time driven activity based costing ( tdabc ) pada usaha kecil menengah (ukm) tape handayani 82 bondowoso. Jurnal Akuntansi Universitas Jember, 1-19. https://doi.org/10.19184/jauj.v11i2.1262.

Ramintang, J., \& Pangemanan, S. (2016). The Application of Activity-Based Costing (ABC) and Job-Order Costing (JOC) at Wisata Bahari Restaurant Manado. Jurnal EMBA : Jurnal Riset Ekonomi, Manajemen, Bisnis Dan Akuntansi, 4(1), 1-10. https://doi.org/10.35794/emba.4.1.2016.11559.

Riediansyaf, Mertzha Dwiputri; Basuki, B. (2014). The Application of Time-Driven Activity-Based Costing In the Hospitality Industry: An Exploratory Case Study. Journal of Applied Management Accounting Research, 12(1), 27-54. https://cmaaustralia.edu.au/ontarget/wpcontent/uploads/2014/06/JAMARv12.1-TDABC-in-Hospitality-Industry.pdf.

Rotikan, G. S. (2013). Penerapan Metode Activity Based Costing dalam Penentuan Harga Produksi pada PT $\begin{array}{llll}\text { Tropica Cocoprima. Jurnal } & \text { EMBA, 1019-1029. }\end{array}$ https://doi.org/10.35794/emba.1.3.2013.2307.

Satria, H. (2017). Penerapan Metode Activity Based Costing Untuk Menentukan Harga Pokok Produksi. Jurnal Benefita, 2(2), 92-101. https://doi.org/10.22216/jbe.v2i2.1265.

Suratinoyo, A. (2013). Penerapan Sistem Abc Untuk Penentuan Harga Pokok Produksi Pada Bangun Wenang Beverage. Jurnal Riset Ekonomi, Manajemen, Bisnis Dan Akuntansi, 1(3), 658-668. https://doi.org/10.35794/emba.v1i3.2134.

Tandiontong, M. (2011). Peranan Activity-Based Costing System Dalam Perhitungan Harga Pokok Terhadap Peningkatan Profitabilitas Perusahaan (Studi Kasus PT Retno Muda Pelumas Prima Tegal). Jurnal Ilmiah Akuntansi, 2(5). https://media.neliti.com/media/publications/220294-peranan-activitybased-costing-system-da.pdf.

Th.A.Sumilat, Z. (2013). Penentuan Harga Pokok Penjualan Kamar Menggunakan Activity Based Costing Pada RSU Pancaran Kasih GMIM. Jurnal EMBA, 1(3), 454-464. https://doi.org/10.35794/emba.1.3.2013.2060.

Winarno, Eko Nugroho, I. H. (2014). Sistem Pendukung Keputusan Uang Kuliah Tunggal Dengan Metode Activity Based Costing. Jurnal Akuntansi Dan Bisnis, 14(2), 108-114. http://dx.doi.org/10.20961/jab.v14i2.156. 